\title{
Distribution of CCR5-Delta32, CCR5 promoter 59029 A/G, CCR2-64I and SDF1-3'A genetic polymorphisms in HIV-1 infected and uninfected patients in the West Region of Cameroon
}

Céline Nguefeu Nkenfou ${ }^{1,2^{*}}$, Linda Chapdeleine Mouafo Mekue ${ }^{3}$, Christelle Tafou Nana ${ }^{4}$ and Jules Roger Kuiate ${ }^{3}$

\begin{abstract}
Background: Genetic variants of the genes encoding Human Immunodeficiency Virus-1 (HIV-1) co-receptors and their ligands, like CC-Chemokine Receptor 5 delta 32 mutation (CCR5-Delta32), CCR5 promoter A/G (Adenine/Guanine), CC-Chemokine Receptor 2 mutation 64 isoleucine (CCR2-64) and the Stromal cell-derived Factor 3'A mutation (SDF1-3'A), are involved in the susceptibility to HIV-1 infection and progression. The prevalence of these mutations varies by Region. However, little is known about their distribution in the population of Dschang, located in the West Region of Cameroon. The prevalence of HIV in the West Region of Cameroon is lower than elsewhere in Cameroon. The objectives of this study were to determine the distribution of four AIDS Related Gene (ARG) variants in HIV-infected and non-infected population of Cameroon especially in the West Region and to estimate the contribution of these variants to the susceptibility or resistance to HIV infection. We also aimed to evaluate the effectiveness of genotyping using dried blood spot (DBS) samples.
\end{abstract}

Methods: A total of 179 participants were recruited from two hospitals in Dschang in the West Region of Cameroon. Their genotypes for CCR5-Delta32, CCR5 promoter 59029A/G, CCR2-64l and SDF1-3'A were analyzed using polymerase chain reaction (PCR) and restriction fragment length polymorphisms.

Results: A total of 179 participants were enrolled in the study. Among them, 32 (17.9\%) were HIV positive and 147 (82.1\%) were HIV negative. The allelic frequencies of these genes were: $0 \%, 49.72 \%, 17.6 \%$ and $100 \%$ respectively for CCR5-Delta32, CCR5 promoter 59029A/G, CCR2-64I and SDF1-3'A. No individual was found to carry the CCR5-Delta 32 mutation. All participants recruited were heterozygous for the SDF1-3'A allele.

Conclusion: Our data suggest that the CCR5-Delta32 cannot account for the protection as it was completely absent in our population. SDF1-3'A variants, may be in association with other polymorphisms, may account for the overall protection from HIV-1 infection in participants recruited as everyone carries this allele. The CCR5 promoter 59029 G/G genotype may be associated with the risk for HIV-1 infection in this population, while the CCR2-64I (A/A genotype) may account for the protection against HIV infection. The results of genotyping from fresh blood and DBS were comparable.

Keywords: HIV, AIDS related gene variants, Allelic frequency, Cameroon

\footnotetext{
* Correspondence: nkenfou@yahoo.com

1"Chantal Biya" International Reference Centre for Research on HIV and AIDS

Prevention and Management (CIRCB), P.O. Box 3077, Yaounde-Messa,

Cameroon

${ }^{2}$ Department of Biological Sciences, Higher Teachers' Training College,

University of Yaounde I, Yaounde, Cameroon

Full list of author information is available at the end of the article
} 


\section{Background}

Thirty years after the discovery of HIV as the cause of AIDS there is still no effective vaccine and no cure for this disease. HIV susceptibility shows a consistent level of individual heterogeneity, much of which can be conferred by host genetic variation, some to the virus and some to the immune response. In an effort to discover host factors required for HIV replication, to identify crucial pathogenic pathways, and to reveal the full armament of host defenses, there has been a shift from candidate-gene studies to unbiased genome-wide genetic and functional studies. However, the number of securely identified host factors involved in HIV disease remains small, explaining only approximately $15-20 \%$ of the observed heterogeneity [1].

Humans are constantly in contact with infectious pathogens. Selective pressure may result in genetic changes that may be important to escape infections or to better fight against infection [2].

The unexpected encounter, between HIV and the chemokine system has dramatically advanced our understanding of the pathogenesis of AIDS, opening new perspectives for the development of effective prophylactic and therapeutic measures [3].

A previous survey conducted in 2000 in Cameroon indicated substantial variation in HIV seroprevalence, ranging from $0 \%$ to $18 \%$ among ethnic groups in different villages of Cameroon [4]. A recent report from the national HIV/AIDS committee showed differential HIV prevalence according to the Region; the West Region where the Bamileke people live has one of the lowest rates of HIV prevalence at 2.3\% [5]. Whether genetic variation among ethnic groups can account for or reflect important portions of the differences in HIV seroprevalence among groups in Cameroon is unknown. However, limited information is available about the distribution among overall African populations of host genetic polymorphisms conferring resistance to HIV-1 infection or slowing HIV disease progression. Identifying CCR2-64I, CCR5- L32, CCR5 promoter 59029 A/G and SDF1-3' $A$ allelic variants and their distribution may help understand the burden and course of the disease which may be important in clinical decision making. In the present study, we investigated four ARG variants, in the West Region of Cameroon and analyzed the association of these host gene polymorphisms with HIV serostatus.

Notably, polymorphisms of the genes for CCR5, CCR2 and stromal-derived factor 1 (SDF1) have been found to modulate the susceptibility of individuals to HIV-1 infection and/or the pathogenic progression [6]. However, the real effect of those gene polymorphisms on the susceptibility of individuals to HIV-1 infection and AIDS progression remains controversial.
Individuals who are homozygous for the mutations (CCR5- $\Delta 32 / \Delta 32)$ show high resistance to HIV-1 infection in many ethnic populations [7-10]. However, recent studies found that several individuals with the CCR5$\Delta 32 / \Delta 32$ genotype were HIV-1 positive [11-13]. Furthermore, the distribution of CCR5- $\triangle 32$ frequency varies in different ethnic populations. While a high frequency of CCR5- $\triangle 32$ appears in Caucasians, a very low frequency is evident in Asian people, [10,14-17] and in Africa [18]. A previous report showed no CCR5- $\triangle 32$ allele in seven ethnic populations in Cameroon [19].

Several other polymorphisms in the CCR5 gene have been associated with HIV infection, namely the CCR5$m 303$, the CCR5-59653T and the CCR5 promoter 59029 $A / G$. CCR5 promoter $59029 A / G$ is an $\mathrm{A} / \mathrm{G}$ transition identified at base pair 59029 in the CCR5 promoter. Both promoter alleles are common (43-68\% allelic frequency for 59029-A depending on race) [20]. The CCR5 promoter $59029 \mathrm{~A} / \mathrm{G}$ distribution and its impact in HIV1 infection in Cameroon have not yet been explored.

In HIV-1/AIDS, the mutation of valine (V) to isoleucine (I) in CCR2 has not been shown to affect susceptibility to infection, but HIV-infected persons, heterozygous or homozygous for this mutation appeared to progress to AIDS or death more slowly [21]. This may not be by its action directly but, by the linkage to other haplotype mutations (example CCR5- $\triangle 32$, CCR5-59653T). Some previous studies, however, have not confirmed this effect on progression to disease [22]. The delay of disease is achieved through a long asymptomatic phase of the disease. Studies on infected commercial sex workers in Nairobi, Kenya, suggested that the presence of the mutation helped to explain the slow progression in $21 \%$ to $46 \%$ of slow progressors [23]. One mutation linked to the CC-chemokine receptor, CCR2-64I is present mostly in Africa compared to the rest of world. However, despite the high prevalence of HIV in Africa, the CCR2-64I mutation alone is but one possible factor in HIV/AIDS development. The frequency of this mutation is as follows: in overall Africa (17.2\%), Gambia (4.3\%), and Central Africa (20.2\%) [24]. In some Spanish populations the prevalence is also high $(14 \%-30 \%)$ [25].

SDF1 is the principal ligand of CXCR4. In SDF1-3' A, a $\mathrm{G}$ to A mutation at position 801 relative to the ATG start codon in the non-coding Region of the $S D F-1$ gene, has been shown to inhibit AIDS progression [26,27]. HIV infected patients homozygous for this mutation exhibited a significantly delayed progression to AIDS and an even more significant decrease in mortality [27]. It has been known that the SDF1-3'A mutation could result in increased SDF1 production, resulting in delayed infection due to the strong competition with the CXCR-4 chemokine receptor. Other groups, however, did not observe a similar inhibitory effect, but instead reported that patients 
who were homozygous for the SDF1-3'A variant had more-rapid disease progression [28-31]. Importantly, the frequency of the $S D F 1-3$ 'A mutation varies in different ethnic populations [32].

We are reporting in this article the distribution of four ARG's in Dschang in the West Region of Cameroon.

\section{Methods}

\section{Subjects and sample collection}

Participants of both sexes were recruited from patients consulting at the district hospital and the Saint Vincent de Paul hospital in Dschang city. Only consenting participants were enrolled and a questionnaire was administered. Experimental protocols were approved by the National ethics committee under the $\mathrm{N}^{\circ} 269 / \mathrm{CNE} / \mathrm{SE} / 2011$. Written informed consent was obtained from each participant. Five $\mathrm{ml}$ of blood were collected in EDTA tubes from each participant. The plasma was used for the diagnosis of HIV and the Buffy coat was used as a source of genomic DNA for genotyping.

\section{HIV testing}

The presence of HIV antibodies was detected using Determine HIV 1/2 test (Alere, 357 Matsuhidai, Matsuda-shi, Chiba, 270-2214 Japan) and confirmed using the Genie III HIV-1/HIV-2 test (Biorad 3, Bd Raymond Poincaré, 92430 Marnes La Coquette, France).

\section{Isolation of genomic DNA and genotyping of CCR5- $\triangle 32$,} CCR5 promoter 59029 A/G, CCR2-64I and SDF1-3'A

Genomic DNA was extracted from the Buffy coat using the QiaAmp DNA mini kit (Qiagen S.A 3 Avenue du Canada, LP 809, 91974 Courtaboeuf Cedex, France), according to the manufacturer's instructions.

The CCR5- $\triangle 32$, CCR5 promoter 59029 A/G, CCR264I, and SDF1-3'A genetic variants in individual subjects were characterized by PCR followed by RFLP detection using the specific primers and restriction endonucleases as described previously [33,34]. The sequences of primers and the restriction enzymes used are presented in Table 1. All restriction enzymes used in this work were purchased from New England Biolabs, 240 County Road, Ipswich, MA, 01938-2723, USA, and used according to their instructions.

The CCR5- $\triangle 32$ gene fragment amplified by the above mentioned primers will produce two types of fragments and three types of genotypes depending on the presence or not of the mutation: a $262 \mathrm{bp}$ fragment if the person does not have the $\Delta 32$ mutation on its two alleles (wild type), a 230 fragment if the person is homozygous for the deletion (mutant) and two fragments 262 and 230 if the person is heterozygous.

The CCR5-promoter 59029 A/G fragment amplified by the above mentioned primers is $498 \mathrm{bp}$. The A to $\mathrm{G}$ mutation introduces a recognition site for the $B s p 1286 \mathrm{I}$ restriction enzyme. If there is mutation, then $B s p 1286 \mathrm{I}$ will cleave and produce two fragments of 453 and $45 \mathrm{bp}$ respectively if the person is homozygous for the mutation. If the person is heterozygous there will be three fragments on the gel of $498 \mathrm{bp}, 453 \mathrm{bp}$ and $45 \mathrm{bp}$ respectively. If a person has the wild type allele, then only one fragment of $498 \mathrm{bp}$ will be seen on the gel.

The CCR2 gene fragment amplified by the primers in Table 1 is $380 \mathrm{bp}$. The 64I mutation introduces a recognition site for FokI. In this case, FokI will cleave at its recognition site and produce two fragments of 215 and 165 bp respectively if the person is homozygous for the mutation. If a person is heterozygous there will be three fragments on the gel at $380 \mathrm{bp}, 215 \mathrm{bp}$ and $165 \mathrm{bp}$ respectively. There will be just one fragment at $380 \mathrm{bp}$ if the CCR2 gene fragment does not have the mutation.

The SDF1-3' A gene fragment amplified by the designed primers (in Table 1) is $302 \mathrm{bp}$. The A to G mutation removes the recognition sequence specific for MspI. If there is a mutation, then the enzyme $M s p I$ will not cleave and only the $302 \mathrm{bp}$ fragment will be present. If the person does not carry the mutation (homozygous wild type); the Msp I digestion will produce two fragments of 202 and 100

Table 1 Primers, amplicon size, enzymes, expected fragments size after digestion and references used for genotyping

\begin{tabular}{|c|c|c|c|c|c|}
\hline Genes & Primers sequence $\left(5^{\prime}-3^{\prime}\right)$ & $\begin{array}{l}\text { Size of the } \\
\text { amplicon (bp) }\end{array}$ & $\begin{array}{l}\text { Enzyme used } \\
\text { for the RFLP }\end{array}$ & Expected fragments size (bp) & Reference \\
\hline \multirow[t]{2}{*}{$C C R 5-\triangle 32$} & CTTCATCATCCTCCTGACAATCG & $262(w t)$ & None & 262 or 230 & [33]Kristiansen et al., 2001 \\
\hline & GACCAGCCCCAAGTTGACTATC & 230 (mut) & & & \\
\hline \multirow{2}{*}{$\begin{array}{l}\text { CCR5 promoter } \\
A / G\end{array}$} & TGGGGTGGGATAGGGGATAC & 498 & Bsp12861 & $453+45$ & [33]Kristiansen et al., 2001 \\
\hline & TGTATTGAAGGCGAAAAGAATCAG & & & & \\
\hline \multirow[t]{2}{*}{ CCR2-641 } & GGATTGAACAAGGACGCATTTCCCC & 380 & Fokl & $215+165$ & [34]Magierowska et al., 1999 \\
\hline & TTGCACATTGCATTCCCAAAGACCC & & & & \\
\hline \multirow[t]{2}{*}{ SDF1-3'A } & CAGTCAACCTGGGCAAAGCC & 302 & Mspl & $202+100$ & [33]Kristiansen et al., 2001 \\
\hline & AGCTTTGGTCCTGAGAGTCC & & & & \\
\hline
\end{tabular}


bp respectively. If the person is heterozygous there will be three fragments on the gel at 302 bp, 202 bp and 100 bp respectively.

\section{Genotyping using DBS samples}

To evaluate the performance of genotyping using DBS samples, 50 random blood samples were spotted on Whatman paper and allowed to dry at room temperature in the dark [35]. DNA extraction was done on these DBS using a QiaAmp DNA minikit according to the manufacturer's instruction. Eluted DNA was amplified and digested as described above. This evaluation was done on the CCR2-64I gene. Results obtained were compared to those obtained from fresh Buffy coat.

\section{Statistical analysis}

The allelic frequencies were calculated as $(h+2 H) / 2 N$, where $H$ is the number of samples with a homozygous mutation genotype, $h$ is the number with a heterozygous mutation genotype and $N$ the total number of samples. The frequency was further analyzed by Hardy-Weinberg equilibrium (HWE) analysis. The HWE was performed in the population using PopGen software. The differences in the frequency of each genetic variant between HIV-1 seronegative and HIV-1 seropositive groups were determined by a Chi-square test. A value of $P<0.05$ was considered statistically significant.

\section{Results}

\section{Study population}

To determine the distribution of CCR5- $\triangle 32$, CCR5 promoter 59029 A/G, CCR2-64I and SDF1-3'A genetic variants, we recruited 179 subjects living in Dschang in the West Region of Cameroon, who were either HIV-1 seropositive or seronegative. They were all aged between 16 and 81 years old, with the median age of 27 . There were $123(68.7 \%)$ female and $56(31.3 \%)$ male. The epidemiological characteristics of the subjects are presented in Table 2.

Table 2 Demographic characteristics of study participants according to the HIV-1 sero status, age and sex

\begin{tabular}{|c|c|c|c|c|c|c|c|}
\hline \multirow[b]{2}{*}{ Age group $^{a}$} & \multicolumn{2}{|c|}{ Female } & \multicolumn{2}{|l|}{ Male } & \multicolumn{2}{|l|}{ Total } & \multirow[t]{2}{*}{ Overall } \\
\hline & HIV+ & HIV- & HIV+ & HIV- & Female & Male & \\
\hline $16-24$ & 6 & 43 & 3 & 21 & 49 & 24 & 73 \\
\hline $25-34$ & 10 & 36 & 0 & 17 & 46 & 17 & 62 \\
\hline $35-44$ & 8 & 13 & 4 & 2 & 21 & 6 & 27 \\
\hline $45-54$ & 1 & 2 & 0 & 9 & 3 & 9 & 12 \\
\hline $55-81$ & 0 & 4 & 0 & 0 & 4 & 0 & 5 \\
\hline Total & 25 & 98 & 7 & 44 & 123 & 56 & 179 \\
\hline
\end{tabular}

\section{HIV serology}

From the 179 participants, 147 (82.1\%) were HIV negative. Thirty two were confirmed to be HIV positive (17.9\%) of which 25 were female and 7 were male. $41 \%$ of the HIV positive participants were already on ARV treatment.

\section{Evaluation of the genotyping using DBS}

DNA extraction was done successfully from dried blood spots. The amplification of the $380 \mathrm{bp}$ of the CCR2 gene fragment was done according to the method developed by Magierowska [34]. The results obtained were $100 \%$ concordant with those obtained from fresh blood. So DBS samples can be confidently used for genotyping.

\section{Genotyping}

The allelic frequencies of CCR5- $\triangle 32$ (0\%), CCR5 promoter 56029 A/G (49.72\%), CCR2-64I (17.60\%) and $S D F 1-3$ 'A (100\%) in the population were reported. These results are presented in Table 3 for the whole population and Table 4 according to the HIV serostatus.

No CCR5- $\triangle 32$ mutation was identified in our study group either as homozygous or heterozygous. For the CCR5 promoter 59029 A/G, prevalence of $62.6 \%$ of heterozygous, $17 \%$ of wild type and $18.4 \%$ double mutant were identified in our study group. This is the first description of the prevalence of this ARG variant in Cameroon. The prevalence of $2.7 \%, 29.6 \%$ and $67.6 \%$ was found respectively for the CCR2-64I homozygous mutant, heterozygous and homozygous wild type. For the SDF1-3'A gene neither wild type nor homozygous

Table 3 Distribution of CCR5-432, CCR5 promoter 59029 A/G, CCR2-64I and SDF1-3'A in HIV seropositive and seronegative groups

\begin{tabular}{|c|c|c|c|}
\hline Gene variants & & $\begin{array}{l}\text { HIV positive } \\
\text { N (\%) }\end{array}$ & $\begin{array}{l}\text { HIV negative } \\
\text { N (\%) }\end{array}$ \\
\hline \multirow[t]{3}{*}{$C C R 5-\triangle 32$} & $W t / w t^{a}$ & 32 (100) & $147(100)$ \\
\hline & $\mathrm{Wt} / \triangle 32^{\mathrm{b}}$ & $0(0.0)$ & $0(0.0)$ \\
\hline & $\Delta 32 / \Delta 32^{c}$ & $0(0.0)$ & $0(0.0)$ \\
\hline \multirow[t]{3}{*}{ CCR5 promoter 59029 A/G } & $\mathrm{A} / \mathrm{A}^{\mathrm{a}}$ & $5(15.62)$ & 29 (19.72) \\
\hline & $A / G^{b}$ & $17(53.12)$ & $95(64.62)$ \\
\hline & $\mathrm{G} / \mathrm{G}^{\mathrm{C}}$ & $10(31.25)$ & $23(15.64)$ \\
\hline \multirow[t]{3}{*}{$C C R 2-641$} & $\mathrm{G} / \mathrm{G}^{\mathrm{a}}$ & $24(75)$ & $97(66.1)$ \\
\hline & $G / A^{b}$ & $8(25)$ & 45 (30.6) \\
\hline & $\mathrm{A} / \mathrm{A}^{\mathrm{c}}$ & $0(0.0)$ & $5(3.4)$ \\
\hline \multirow[t]{3}{*}{ SDF1-3'A } & $G / G^{a}$ & $0(0.0)$ & $0(0.0)$ \\
\hline & $G / A^{b}$ & $32(100)$ & $147(100)$ \\
\hline & $\mathrm{A} / \mathrm{A}^{\mathrm{c}}$ & $0(0.0)$ & $0(0.0)$ \\
\hline
\end{tabular}

a. Wild type homozygotes.

b Heterozygotes.

c Mutant type homozygotes. 
Table 4 Allelelic frequencies of the four ARG ${ }^{*}$ variants in the study population

\begin{tabular}{llll}
\hline Alleles & $\begin{array}{l}\text { Quantity } \\
(\mathbf{n})\end{array}$ & $\begin{array}{l}\text { Subjects } \\
(\mathbf{N})\end{array}$ & $\begin{array}{l}\text { Allelic frequency } \\
(\mathbf{p})\end{array}$ \\
\hline CCR5- $\triangle 32$ & 0 & 179 & 0 \\
$\begin{array}{l}\text { CCR5promoter 59029 } \\
w t^{a}\end{array}$ & 180 & 146 & 0,503 \\
$\begin{array}{l}C C R 5 \text { promoter 59029 } \\
m t^{b}\end{array}$ & 178 & 145 & 0,497 \\
$C C R 2 w t^{a}$ & 295 & 174 & 0,824 \\
CCR2 $m t^{b}$ & 63 & 58 & 0,176 \\
SDF1-3'A & 179 & 179 & 1 \\
\hline
\end{tabular}

${ }^{\circ}$ AIDS related gene. a. Wild type. b Mutant.

mutants were seen. Instead all 179 participants exhibited a heterozygous genotype.

The HWE analysis revealed that all genetic variants for CCR5 promoter $59029 \mathrm{~A} / \mathrm{G}$ and CCR2-64I in the studied population were in equilibrium $(P>0.05)$ (Table 5$)$.

\section{Allelic frequencies and HIV serostatus}

Allelic frequencies in relation to the HIV serostatus are presented in Table 6. The allele frequency of the CCR5 promoter 59029 A/G in HIV-1 seropositive group (57.8\%) was not significantly different from that $(48.6 \%)$ in the seronegative group $(P=0.19)$. Importantly, there was a significant difference in G/G genotype between HIVseropositive and HIV seronegative $(34.3 \%$ and $15.6 \%$ respectively, $\mathrm{P}=0.049$ ), suggesting that the CCR5 promoter $59029 \mathrm{G} / \mathrm{G}$ allele may be associated with the risk of HIV-1 infection in our population. This is contradictory to a previous study where the CCR5 promoter 59029-G/G appears to be protective relative to CCR5 59029-A/A [20].

Table 5 Allele frequency and $\mathrm{HWE}^{a}$ analysis of four $\mathrm{ARG}^{b}$ in a population of West Cameroon

\begin{tabular}{|c|c|c|c|c|c|c|c|c|}
\hline \multirow[t]{2}{*}{$\begin{array}{l}\text { Gene } \\
\text { variants }\end{array}$} & \multirow[b]{2}{*}{ genotype } & \multicolumn{3}{|c|}{$\begin{array}{l}\text { HIV } \\
\text { positive }\end{array}$} & \multicolumn{3}{|c|}{$\begin{array}{l}\text { HIV } \\
\text { Negative }\end{array}$} & \multirow{2}{*}{$\begin{array}{l}\text { Total } \\
\text { Freq } \\
(\%)\end{array}$} \\
\hline & & $\begin{array}{l}\text { Freq } \\
(\%)\end{array}$ & $x^{2}$ & $P$ & $\begin{array}{l}\text { Freq } \\
(\%)\end{array}$ & $x^{2}$ & $P$ & \\
\hline \multirow[t]{2}{*}{$C C R 5-\triangle 32$} & Wt & 100 & & & 100 & & & 100 \\
\hline & $\Delta 32$ & 0 & & & 0 & & & 0 \\
\hline \multirow{2}{*}{$\begin{array}{l}\text { CCR5 } \\
\text { promoter } \\
\text { A/G }\end{array}$} & A & 42.2 & 0.54 & 0.675 & 51.4 & 12.6 & 0.001 & 46.8 \\
\hline & G & 57.8 & & & 48.6 & & & 53.2 \\
\hline \multirow[t]{2}{*}{ CCR2- 641} & G & 87.5 & 0.74 & 0.207 & 81.3 & 0.16 & 0.75 & 84.4 \\
\hline & A & 12.5 & & & 18.7 & & & 15.6 \\
\hline \multirow[t]{2}{*}{$S D F 1-3^{\prime} A$} & G & 50 & 300.25 & & 50 & 300.25 & & 50 \\
\hline & $A$ & 50 & & & 50 & & & 50 \\
\hline
\end{tabular}

a. Hardy-Weinberg equilibrium. b AIDS related gene.
Table 6 Allelic frequencies of CCR5 promoter A/G and CCR2 64I and HIV serostatus in a population of west Cameroon

\begin{tabular}{|c|c|c|c|c|c|c|c|c|}
\hline \multicolumn{2}{|c|}{ Allelic genotypes } & \multicolumn{3}{|c|}{ HIV Seropositive } & \multicolumn{3}{|c|}{ HIV Seronegative } & \multirow{2}{*}{$\frac{\text { Total }}{\text { Freq }^{\mathrm{a}} \%}$} \\
\hline & & Freq $^{\mathrm{a}} \%$ & $x 2$ & $P$ & Freq\% & $x 2$ & $P$ & \\
\hline \multirow{2}{*}{$\begin{array}{l}\text { CCR5 } P^{*} \\
\text { A/G }\end{array}$} & CCR5 wt & 42,19 & 0,747 & 0,387 & 52,04 & 0,044 & 0,832 & 50,27 \\
\hline & CCR5 mt & 57,81 & 0,794 & 0,372 & 47,96 & 0,034 & 0,853 & 49,72 \\
\hline \multirow[t]{2}{*}{ CCR2 64l } & CCR2 wt & 87,5 & 0,834 & 0,36 & 81,3 & 0,979 & 0,322 & 82,38 \\
\hline & CCR2 $\mathrm{mt}$ & 12,5 & 0,476 & 0,49 & 18,7 & 0,662 & 0,415 & 17,62 \\
\hline
\end{tabular}

The allele frequency of CCR2-64I in the HIV-1 seronegative group $(18.7 \%)$ was not significantly higher than that $(12.5 \%)$ in seropositive group $(P=0.22)$. This suggests that the CCR2-64I allele is unlikely to be associated with the low prevalence of HIV-1 infection in our population.

\section{Discussion}

In our study we have recruited a total of 179 participants, on which the HIV serology test has been performed. We obtained 32 HIV positive patients and 147 HIV negative ones. This gave a seroprevalence of $17.9 \%$ higher than the general prevalence of the west Region that is at 2.3\% [5]. This is explained by the fact that our participants were enrolled among patients consulting at hospitals.

The evaluation of the methodology using DBS in comparison to fresh blood sample was done using the test of Kappa concordance. The kappa of concordance was 0.95 $(p=0.00)$, which means that there was a high concordance between the two methods. So DBS can be used for ARG genotyping.

Studies have revealed a differential distribution of ARG variants according to ethnicity [32]. In particular, it was reported that the frequency of the CCR5- $\triangle 32$ was high in Caucasians, but low or even absent in Asians and Africans [18]. The distribution of the CCR2-64I allele in South Africans was 13\%, and in African populations of Kenya it ranged from $21 \%$ to $23 \%$, [23,36] and in 7 ethnicities of Cameroon from 0 to $7.1 \%$ [19]. The frequency of SDF1-3'A ranged widely across ethnic groups, from $3 \%$ to $71 \%$ worldwide and from $3 \%$ to $9 \%$ in Africans [32]. Data on the different genetic frequencies of CCR5- $\triangle 32$, CCR5 promoter $59029 A / G, C C R 2-64 I$ and SDF1-3'A alleles reported in African populations living in different African countries are however sparse. The present study is the second to describe the distribution of CCR5- $\triangle 32$, CCR2-64I and SDF1-3' $A$ in Cameroon. It is the first to describe these distributions in the West Region and that of the CCR5 promoter $59029 \mathrm{~A} / \mathrm{G}$ in Cameroon.

Since no CCR5- $\triangle 32$ allele was found in our population it could not account for the low HIV prevalence in the West Region of Cameroon. As shown by the study of 
Ma [19], CCR5- $\triangle 32$ is extremely rare in Cameroon (0\% as in our study population).

About 50\% (49.72\%) of our population carry the CCR5 promoter 59029 A/G mutation. Looking at the distribution of CCR5 promoter 59029 A/G between the HIV positive and HIV negative, the allelic frequency was the same for the HIV positive and the HIV negative group. But the homozygote G/G seems to be higher in HIV positive group, contradicting previous findings [20].

The distribution of the CCR2-64I in our study population was $17.6 \%$, compared to $31.3 \%$ obtained by Ma [19], from 7 ethnic populations in the South and Central Regions of Cameroon. This mutation is thus high in the Central and South Regions of Cameroon compared to the West Region.

Because in HIV positive and HIV negative individuals the distribution of this allele was the same, this mutation confers no resistance to HIV infection but may be involved in the progression of HIV infection to AIDS. Ma [19] et al. in 2005 found that CCR2-64I delays progression of HIV disease to AIDS and death in men and not in women, by conditional logistic regression analysis with matching on ethnicity and adjustment for differences in age. But a meta-analysis, based on all the published works on CCR2-64I in relation to susceptibility to HIV infection, has concluded that this allele has no effect on reducing the risk of HIV-1 infection [37]. Instead, it may act with CCR5- $\triangle 32$ as haplotypes in delaying HIV infection progression to AIDS [34,38].

We have obtained $100 \%$ frequency of $S D F 1-3{ }^{\prime} A$ in our study population compared to $0-7.1 \%$ obtained by $\mathrm{Ma}$ et al., 2005. Could this high prevalence contribute either alone or linked to another gene as a haplotype to the low prevalence of HIV in this group? This result may be specific to the population studied and also to the small size of the population that may be not representative. We intend to extensively investigate the occurrence of this gene in all 10 Regions of Cameroon and on a larger population. Such a larger study may lead to an explanation for our current results. If the exclusive presence of this one allele is confirmed, this may have been selected in an early population that was exposed to HIV or some related disease and the beneficial mutation transmitted from generation to generation. A high frequency of SDF1-3'A (71\%) was also observed in the Oceanian population in New Guinea, [32] where the human presence dates back at least 40,000 years to the oldest human migrations out of Africa. The prevalence of HIV in Papua New Guinea was $1.5 \%$ in 2007 and it decreased to $0.9 \%$ in 2009.

The CCR5- $\triangle 32$ and CCR2-64I alleles have been shown to have a strong protective effect on progression of HIV1 infection, but SDF1-3' $A$ homozygosity carried no such protection [31]. This mutation is associated with the onset of AIDS progression. The protective effect of CCR2-
$64 I$ is dominant, whereas that of $S D F 1-3 ' A$ is recessive. Surprisingly, the SDF1-3'A homozygote has also shown a possible protection against HIV-1 infection [26,27]. Based on the small size population studied, SDF1-3' $A$ heterozygosity may contribute to low HIV/AIDS infection in the West Region of Cameroon.

The combinations of the genotype at loci CCR5 promoter and CCR2 in HIV positive individuals and HIV negative individuals were analyzed. As shown in the Table 7, $P$ values of $0.760,0.134,1,0.305$ and 0.814 were obtained for the five combinations. These results demonstrate that none of the combinations can account for the low prevalence of HIV in the West Region of Cameroon.

The $\chi^{2}$ tests show that the CCR5 promoter 59029 A/G and CCR2-64I polymorphism were in equilibrium from generation to generation (the $X^{2}$ value > 3.84). The observed genotype frequencies had no significant difference from the frequencies expected in each group of polymorphisms. In light of the prevalence of these mutations we can say that these mutations were present in our population since early times. The presence of these mutations worldwide would imply that these mutations arose prior to the dispersal of modern Homo sapiens from an African ancestral population more than 100000 years ago [32].

It is known that following infection with HIV-1, the rate of clinical disease progression varies between individuals. Factors such as host susceptibility, genetics and immune function [39], health care and co-infections [40], as well as viral genetic variability [41], may affect the rate of progression to AIDS. Many studies have looked at the genetic viral distinctions that might explain

\section{Table 7 Combination of the gene variants of CCR5 promoter A/G and CCR2 64 I and HIV serostatus in a population of west Cameroon}

\begin{tabular}{|c|c|c|c|c|}
\hline CCR5 $P^{*}$ & CCR2-64I & $\begin{array}{l}\text { HIV Seropositive } \\
\qquad(n=32)\end{array}$ & $\begin{array}{l}\text { HIV Seronegative } \\
\qquad(n=147)\end{array}$ & $\begin{array}{l}\text { P- } \\
\text { value }\end{array}$ \\
\hline Wt $(A / A)$ & Wt (G/G) & 4 & 16 & 0.760 \\
\hline $\mathrm{Mt}(\mathrm{G} / \mathrm{G})$ & Wt $(G / G)$ & 9 & 24 & 0.134 \\
\hline Wt $(A / A)$ & $\mathrm{Mt}(\mathrm{A} / \mathrm{A})$ & & & \\
\hline $\begin{array}{l}\text { Hetero } \\
(\mathrm{A} / \mathrm{G})\end{array}$ & $\mathrm{Mt}(\mathrm{A} / \mathrm{A})$ & 1 & 4 & 1 \\
\hline $\mathrm{Mt}(\mathrm{G} / \mathrm{G})$ & $\begin{array}{l}\text { Hetero } \\
(G / A)\end{array}$ & & & \\
\hline $\begin{array}{l}\text { Hetero } \\
(\mathrm{A} / \mathrm{G})\end{array}$ & Wt $(G / G)$ & 12 & 70 & 0.305 \\
\hline Wt $(A / A)$ & $\begin{array}{l}\text { Hetero } \\
(G / A)\end{array}$ & & & \\
\hline Mt $(G / G)$ & $M t(A / A)$ & 0 & 0 & \\
\hline $\begin{array}{l}\text { Hetero } \\
(\mathrm{A} / \mathrm{G})\end{array}$ & $\begin{array}{l}\text { Hetero } \\
(G / A)\end{array}$ & 6 & 33 & 0.814 \\
\hline
\end{tabular}

*. Promoter.

Wt: wild type, Mt: mutant, Hetero: heterozygote. 
delayed HIV progression. Considerable research investigating the viral genotype has focused on deletions in the nef gene of HIV seen in some nonprogressors. While many researchers have observed defective nef gene alleles in long term nonprogressors (LTNP), others have not [42-45]. Other researchers have focused on human leukocyte antigen (HLAmolecules $[34,46,47]$. All these factors interplay to affect the acquisition the resistance or the progression into HIV/AIDS.

\section{Conclusion}

In summary, we investigated the distribution of four ARG variants in HIV seropositive and seronegative population. Not surprisingly, we found no CCR5 32 allele. Surprisingly, all the subjects exhibited the $S D F 1-3$ ' $A$ mutation as heterozygous. The frequency of CCR5 promoter G/G in HIV seropositive was significantly higher than that in HIV seronegative. Therefore, these data suggest that the CCR5 promoter $G / G$ variant together with other factors may be associated with a risk for HIV infection. The distribution of CCR2-64I was similar in HIV positive and HIVnegative group, and could not be attributed any impact on HIV in our population.

From the study done on the four ARG variants and in light of the limited size of the population, further studies are needed on a larger population to provide more conclusive results and to define the role if any of $S D F 1-3^{\prime} A$ in HIV prevalence in our population. Other ARG should also be studied including HLA gene families, as the effects of the gene variants are likely to be associative.

In light of the disparities in the distribution of ARG by ethnicity, and the contradictory effect of these ARG's on HIV susceptibility or progression, we suggest that studies be done on more population groups and that ethnicity must be taken into account. A more extensive metaanalysis on larger data sets may lead to conclusive results.

\begin{abstract}
Abbreviations
A: Adenine; AIDS: Acquired Immunodeficiency syndrome; ARG: AIDS Related Genes; CCR2: CC-Chemokine Receptor 2; CCR5: CC-Chemokine Receptor 5; CXCR4: CX-Chemokine Receptor 4; DBS: Dried Blood Spot; DNA: Deoxyribonucleic acid; G: Guanine; HIV: Human Immunodeficiency virus; I: Isoleucine; PCR: Polymerase Chain Reaction; RFLP: Restriction Fragment Length Polymorphism; SDF: Stromal cell-derived Factor; V: Valine.
\end{abstract}

\section{Competing interests}

We have no conflicts of interest in the conduct of this study.

\begin{abstract}
Authors' contributions
All authors contributed in the study and they have all approved the final version for publication. CNN: Conception, design, data analysis, manuscript preparation and revision, LCMM: Sample analysis, data acquisition, analysis and manuscript revision, CTN: Sample collection, data acquisition and manuscript revision, JRK: Critical manuscript revision. All authors read and approved the final manuscript.
\end{abstract}

\section{Acknowledgments}

We acknowledge the participants of this study. We also acknowledge the "Chantal Biya" International Reference Centre for Research on HIV and AIDS Prevention and Management (CIRCB) for financial support. We would also thank Dr. Richard Roberts and Prof. Jacques Thèze for the critical review of the manuscript.

\section{Author details}

1"Chantal Biya" International Reference Centre for Research on HIV and AIDS Prevention and Management (CIRCB), P.O. Box 3077, Yaounde-Messa, Cameroon. 'Department of Biological Sciences, Higher Teachers' Training College, University of Yaounde I, Yaounde, Cameroon. ${ }^{3}$ Department of Biochemistry, Faculty of Sciences, University of Dschang I, Dschang, Cameroon. ${ }^{4}$ Department of Parasitology, Faculty of Sciences, University of Dschang I, Dschang, Cameroon.

Received: 2 January 2013 Accepted: 18 July 2013 Published: 23 July 2013

\section{References}

1. An P, Winkler CA: Host genes associated with HIV/AIDS: advances in gene discovery. Trends Genet 2010, 26:119-131.

2. Barreiro LB, Murci LQ: From evolutionary genetics to human immunology. How selection shapes host defense genes. Nat Rev Genet 2010, 11:17-30.

3. Lusso P: HIV and the chemokine system: 10 years later. EMBO J 2006, 25:447-456.

4. Nyambi P, Zekeng L, Kenfack H, Tongo M, Nanfack A, Nkombe I, Ndonko F, Shang J, Burda S, Mbah H, Agyingi L, Nadas F, Zolla-Pazner S, Marmor M: HIV infection in rural villages of Cameroon. J Acquir Immune Defic Syndr 2002, 31:506-513.

5. NIS (National Institute of Statistics): Rapport préliminaire sur la prévalence du VIH Cameroun. Cameroon; 2012. www.measuredhs.com/pubs/pdf/PR16/PR16.pdf.

6. Reiche EM, Bonametti AM, Voltarelli JC, Morimoto HK, Watanabe MA: Genetic polymorphisms in the chemokine and chemokine receptors: impact on clinical course and therapy of the human immunodeficiency virus type 1 infection (HIV-1). Curr Med Chem 2007, 14:1325-1334.

7. Jang DH, Choi BS, Kim SS: The effects of rantes/CCR5 promoter polymorphisms on HIV disease progression in HIV-infected Koreans. Int Journal of Immunogenetic 2008, 35:101-105.

8. Jlizi A, Edouard J, Fadhlaoui-Zid K, Frigi S, Debré P, Slim A, Theodorou I, El Gaaied AB, Carpentier W: Identification of the CCR5-delta32 HIV resistance allele and new mutations of the CCR5 gene in different Tunisian populations. Hum Immunol 2007, 68:993-1000.

9. Salem AH, Batzer MA: Distribution of the HIV resistance CCR5-delta32 allele among Egyptians and Syrians. Mutat Res 2007, 616:175-180.

10. Verma R, Gupta RB, Singh K, Bhasin R, AnandShukla A, Chauhan SS, Luthra K Distribution of CCR5delta, 32, CCR2-64I and SDF1-3'A and plasma levels of SDF1 in HIV-1 seronegative north Indian. J Clin Virol 2007, 38:198-203.

11. Balotta C, Bagnarelli P, Violin M, Ridolfo AL, Zhou D, Berlusconi A, Corvasce S, Corbellino M, Clementi M, Clerici M, Moroni M, Galli M: Homozygous delta 32 deletion of the CCR-5 chemokine receptor gene in an HIV-1-infected patient. AIDS 1997, 11:67-71.

12. Biti R, French R, Young J, Bennetts B, Stewart G, Liang T: HIV-1 infection in an individual homozygous for the CCR5 deletion allele. Nat Med 1997, 3:252-253.

13. O'Brien SJ, Moore JP: The effect of genetic variation in chemokines and their receptors on HIV transmission and progression to AIDS. Immunology Review 2000, 177:99-111.

14. Kaur G, Rapthap CC, Kumar N, Kumar S, Neolia S, Mehra NK: Frequency distribution of cytokine gene Polymorphism in the CCR5 gene promoter and HIV-1 infection in north Indians. Hum Immunol 2007, 68:454-461.

15. Liu H, Nakayama EE, Theodorou I, Nagai Y, Likanonsakul S, Wasi C, Debre P, Iwamoto A, Shioda T: Polymorphisms in CCR5 chemokine receptor gene in Japan. Int Journal of Immunogenetics 2007, 34:325-335.

16. Wang FS, Hong WG, Cao $Y$, Liu MX, Jin L, Hu LP, Wang Z, Feng TJ, Hou J, Zhang B, Shi M, Xu DP, Lei ZY, Wang B, Liu ZD, Ye JJ, Peng L, Qiu Y, Winkler C: Population survey of CCR5 delta32, CCR5 m303, CCR2-64l, and SDF1-3'A allele frequencies in indigenous chinese healthy individuals, and in HIV-1-infected and HIV-1-uninfected individuals in HIV-1 risk groups. J Acquir Immune Defic Syndr 2003, 32:124-130.

17. Yudin NS, Vinogradov SV, Potapova TA, Naykova TM, Sitnikova W, Kulikov IV, Khasnulin VI, Konchuk C, Vloschinskii PE, Ivanov SV, Kobzev VF, Romaschenko AG, Voevoda MI: Distribution of CCR5-delta 32 gene deletion across the Russian part of Eurasia. Human Genetic 1998, 102:695-698. 
18. Sabeti $P C$, Walsh $E$, Schaffner SF, Varilly $P$, Fry B, Hutcheson HB, Cullen $M$, Mikkelsen ST, Roy J, Patterson N, Cooper R, Reich D, Altshuler D, O'Brien S, Lander ES: The case for selection at CCR5-Delta32. PLoS Biol 2005, 3:e378.

19. Ma L, Marmor M, Zhong $P$, Ewane L, Su B, Nyambi P: Distribution of CCR2-64I and SDF1-3'A Alleles and HIV Status in 7 Ethnic Populations of Cameroon. J Acquir Immune Defic Syndr 2005, 40:89-95.

20. McDermott DH, Zimmerman PA, Guignard F, Kleeberger CA, Leitman SF, Murphy PM: CCR5 promoter polymorphism and HIV-1 disease progression Multicenter AIDS Cohort Study (MACS). Lancet 1998, 352:866-870.

21. Mulherin SA, O'Brien TR, loannidis JP, Goedert JJ, Buchbinder SP, Coutinho RA, Jamieson BD, Meyer L, Michael NL, Pantaleo G, Rizzardi GP, Schuitemaker H, Sheppard HW, Theodorou ID, Vlahov D, Rosenberg PS: International Meta-Analysis of HIV Host Genetics: Effects of CCR5-Delta32 and CCR2-64I alleles on HIV-1 disease progression: the protection varies with duration of infection. AIDS 2003, 17:377-387.

22. Schinkel J, Langendam MW, Coutinho RA, Krol A, Brouwer M, Schuitemaker $\mathrm{H}$ : No evidence for an effect of the CCR5 $\triangle 32 /^{+}$and $C C R 2 b$ $64 I /^{+}$mutations on human immunodeficiency virus (HIV)-1 disease progression among HIV-1-infected injecting drug users. Journal of Infectious Disease 1999, 179:825-831.

23. Anzala AO, Ball TB, Rostron T, O'Brien SB, Plummer FA, Rowland-Jones SL: CCR2-64I allele and genotype association with delayed AIDS progression in African women. Lancet 1998, 35:1632-1633.

24. Jeremy JM, Lily Honga RK, John PM, Leondios GK: Global distribution of the CCR2-64I/CCR5-59653T HIV-1 disease-protective haplotype. AIDS 2000, 14:483-489.

25. Angelina XA, Rogério GS, Juliana LS, Bernardo G: Distribution of the CCR2-64l allele in three Brazilian ethnic groups. Genet Mol Biol 2003 26:241-243.

26. Tiensiwakul P: Stromal cell-derived factor (SDF) 1-3'A polymorphism may play a role in resistance to HIV-1 infection in seronegative high-risk. Thais Intervirology 2004, 47:87-92

27. Winkler C, Modi W, Smith MW, Nelson GW, Wu X, Carrington M, Dean M, Honjo T, Tashiro K, Yabe D, Buchbinder S, Vittinghoff E, Goedert JJ, O'Brien TR, Jacobson LP, Detels R, Donfield S, Willoughby A, Gomperts E, Vlahov D, Phair J: Hemophilia Growth and Development Study (HGDS), Multicenter AIDS Cohort Study (MACS), Multicenter Hemophilia Cohort Study (MHCS), San Francisco City Cohort (SFCC), O'Brien SJl: Genetic restriction of aids pathogenesis by an sdf-1 chemokine gene variant. Alive study, hemophilia growth and development study (hgds), multicenter aids cohort study (macs), multicenter hemophilia cohort study (mhcs), San Francisco city cohort (sfcc). ALIVE Study. Science 1998, 279:389-393.

28. Van Rij RP, Broersen S, Goudsmit J, Coutinho RA, Schuitemaker H: The role of a stromal cell-derived factor- 1 chemokine gene variant in the clinical course of HIV-1 infection. AIDS 1998, 12:85-90.

29. Brambilla A, Villa C, Rizzardi G, Veglia F, Ghezzi S, Lazzarin A, Cusini M, Muratori S, Santagostino E, Gringeri A, Louie LG, Sheppard HW, Poli G, Michael NL, Pantaleo G, Vicenzi E: Shorter survival of SDF1-3'A/3'A homozygotes linked to CD4+ T-cell decrease in advanced human immunodeficiency virus type 1 infection. Journal of Infectious Disease 2000, 182:311-315

30. Lathey JL, Tierney C, Chang SP, Aquila RT, Bettendorf DM, Alexander HC, Santini CD, Hughes AM, Barroga CF, Spector SA, Landes JE, Hammer MS, Katzenstein DA: The AIDS Clinical Trials Group 175 Virology Team b: Associations of CCR5, CCR2, and Stromal Cell-Derived Factor 1 genotypes with Human Immunodeficiency Virus disease progression in patients receiving nucleoside therapy. J Infect Dis 2001, 184:1402-1411.

31. loannidis JP, Rosenberg PS, Goedert JJ, Ashton LJ, Benfield TL, Buchbinder SP, Coutinho RA, Eugen-Olsen J, Gallart JT, Katzenstein TL, Kostrikis LG, Kuipers H, Louie LG, Malla SA, Margolick JB, Martinez OP, Meyer L, Michael NL, Operskalski E, Pantaleo G, Rizzardi GP, Schuitemaker H, Sheppard HW Stewart GJ GJ, Theodorou ID, Ullum H, Vicenz E, Vlahov D, Wilkinson D, Workman C, Zagury JF, O'Brien TR: International Meta-Analysis of HIV Host Genetics Effects of CCR5-Delta32, CCR2-64I, and SDF1-3'A alleles on HIV-1 disease progression: an international meta-analysis of individual-patient data. Ann Intern Med 2001, 135:782-795.

32. Su B, Jin L, Hu F, Xiao J, Luo J, Lu D, Zhang W, Chu J, Du R, Geng Z: Distribution of two HIV-1-resistant polymorphisms (SDF1-3'A and CCR2-64I) in East Asian and world populations and its implication in AIDS epidemiology. Am J Hum Genet 1999, 65:1047-1053.
33. Kristiansen $\mathrm{TB}$, Knudsen $\mathrm{TB}$, Ohlendorff $\mathrm{S}$, Eugen-Olsen J: A new multiplex PCR strategy for the simultaneous determination of four genetic polymorphisms affecting HIV-1 disease progression. J Immunol Methods 2001, 252:147-151.

34. Magierowska M, Theodorou I, Debré P, Sanson F, Autran B, Rivière Y, Charron D, French ALT, IMMUNOCO Study Groups, Costagliola D: Combined Genotypes of CCR5, CCR2, SDF1, and HLA Genes Can Predict the Long-Term Non progressor Status in HIV-1-Infected Individuals. Blood 1999, 93:936-941.

35. World Health Organisation: WHO Manual for HIV Drug Resistance Testing using Dried Blood Spot Specimens. ; 2010:P7.

36. Williamson C, Loubser SA, Brice B, Joubert G, Smit T, Thomas R, Visagie M, Cooper M, Van der Ryst E: Allelic frequencies of host genetic variants influencing susceptibility to HIV-1 infection and disease in South African populations. AIDS 2000, 14:449-451.

37. Dong-Lin D, Liu S, Zhu H: Association between the CCR2-Val64lle polymorphism and susceptibility to HIV-1 infection: a meta-analysis. Molecular Medicine Reports 2011, 4:181-186.

38. Struyf F, Theolen I, Charlier N, Keyaerts E, Van der Donck I, Wuu J, Van Ranst M: Prevalence of CCR5 and CCR2 HIV-Coreceptor Gene Polymorphisms in Belgium. Hum Hered 2000, 50:304-307.

39. Burastero S, Claudio C, Chiara P, Paola B, Chiara A, Claudia P, Lucia L: Anti-CD4-gp120 complex antibodies in long-term non-progressors HIV-1 positive patients: a role in slowing disease progression? Retrovirology 2006, 3(Suppl 1):36

40. Morgan D, Mahe B, Mayanja J, Whitworth A: Progression to symptomatic disease in people infected with HIV-1 in rural Uganda: prospective cohort study. BMJ 2002, 324:193-196.

41. Campbell GR, Pasquier E, Watkins J, Bourgarel-Rey V, Peyrot V, Esquieu D, Barbier P, De Mareuil J, Braguer D, Kaleebu P, Yirrell DL, Loret EP: The Glutamine-rich Region of the HIV-1 Tat Protein Is Involved in T-cell Apoptosis. J Biol Chem 2004, 279:48197-48204.

42. Deacon A, Tsykin A, Solomon A, Smith K, Ludford-Menting M, Ellett A, Hooke D, McPhee D, Greenway A, Chatfield C, Lawson V, Crowe S, Maerz A, Sonza S, Learmont J, Sullivan J, Cunningham A, Dwyer D, Dowton D, Mills J: Genomic Structure of an Attenuated Quasi Species of HIV-1 from a Blood Transfusion Donor and Recipients. Science 1995, 270:988-991.

43. Greenough T, Brettler D, Kirchhoff F, Alexander L, Desrosiers R, O'Brien S, Somasundaran M, Luzuriaga M, Sullivan J: Long-Term Nonprogressive Infection with Human Immunodeficiency Virus Type 1 in a Hemophilia Cohort. J Infect Dis 1999, 180:1790-1802

44. Brambilla A, Turchetto L, Gatti A, Bovolenta C, Veglia F, Santagostino E, Gringeri A, Clementi M, Poli G, Bagnarelli P, Vicenzi E: Defective nef Alleles in a Cohort of Hemophiliacs with Progressing and Nonprogressing HIV-1 Infection. Virology 1999, 259:349-368.

45. Alexander L, Weiskopf E, Greenough T, Gaddis N, Auerbach M, Malim M O'Brien S, Walker B, Sullivan J, Desrosiers R: Unusual Polymorphisms in Human Immunodeficiency Virus Type 1 Associated with Nonprogressive Infection. J Virol 2000, 74:4361-4376.

46. Klein M, Van der Burg S, Hovenkamp E, Holwerda A, Drijfhout J: Characterization of HLA-B57-restricted human immunodeficiency virus type $1 \mathrm{Gag}$ - and RT-specific cytotoxic T lymphocyte responses. J Gen Virol 1998, 79:2191-2201.

47. Gillespie G, Kaul R, Dong T, Yang HB, Rostron T: Cross-reactive cytotoxic T lymphocytes against a HIV-1 p24 epitope in slow progressors with $B * 57$. AIDS 2002, 16:961-972.

\section{doi:10.1186/1756-0500-6-288}

Cite this article as: Nkenfou et al: Distribution of CCR5-Delta32, CCR5 promoter 59029 A/G, CCR2-64I and SDF1-3'A genetic polymorphisms in HIV-1 infected and uninfected patients in the West Region of Cameroon. BMC Research Notes 2013 6:288. 